\title{
In Quest for Identity and Oppressed Identities in Michelle Cliff's Abeng (1990): An Eco-Feminist Perspective
}

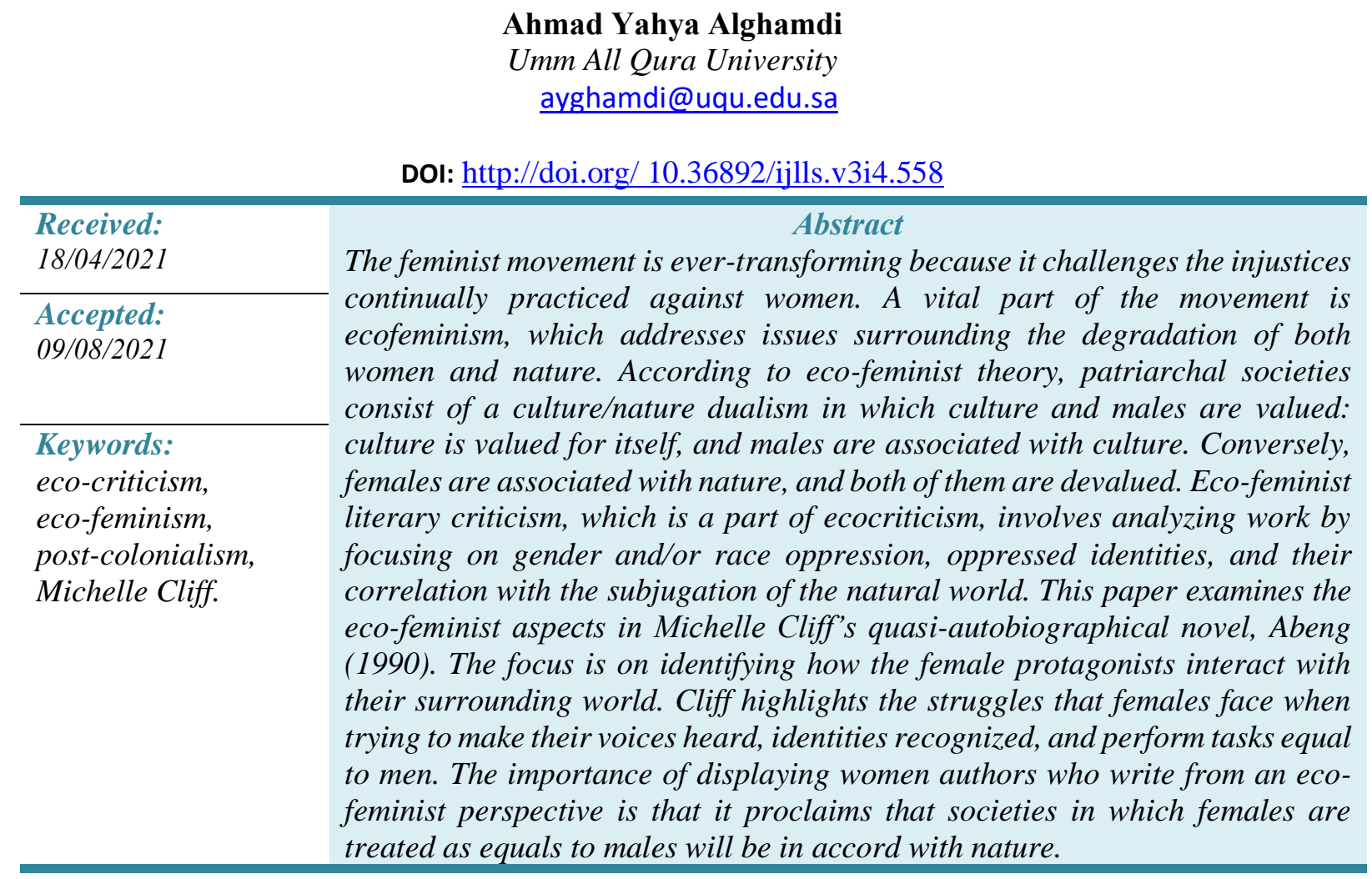

\section{INTRODUCTION}

In contemporary societies, there has been a growing global concern for the sustainability of human life on Earth, brought on by the exhaustion of natural resources and the intensification of global warming. Writers and literary critics have become more sensitive to environmental issues. Therefore, eco-criticism has emerged as a critical and research approach to the literary representations of the relationship between humans and nature. The first person to use the word "eco-criticism" was William Rueckert in his essay Literature and Ecology: An Experiment in Ecocriticism (1978). However, the movement is credited back to the Rachel Carson's environmental exposé Silent Spring (1962). Although works about the environment were scattered across academic disciplines in the late 1970s, a coherent eco-criticism movement did not crystalize until the 1990s, first in the United States and then in the United Kingdom. Among the questions eco-critics address are:

What role does the physical setting play in the plot of a novel? Are the values expressed in this play consistent with ecological wisdom? How can we characterize nature writing as a genre? In addition to race, class, and gender, should a place become a new critical 
category? Do men write about nature differently than women do? In what ways has literacy itself affected humankind's relationship to the natural world? In what ways and to what effect is the environmental crisis seeping into contemporary literature and popular culture? (Glotfelty \& Fromm, 1996, p. xix)

Feminist writers and literary critics have also asked these questions, particularly those that address the status of women in their environments and their representations in literature. The type of eco-criticism that focuses on women's issues is eco-feminist criticism, which involves analyzing the work by focusing on gender and/or race oppression and its correlation with the subjugation of the natural world. The eco-criticism theory and associated ecofeminism movement, which emerged during the 1990s, serve as the lenses through which Abeng in this paper is viewed.

\section{ECO-FEMINISM}

The feminist movement is one of the most transformative because it challenges the injustices perpetrated against women. A vital part of the movement is eco-feminism, which addresses issues surrounding the degradation of both women and nature. According to ecofeminist theory, patriarchal societies consist of a culture/nature dualism in which culture is valued, and males associated with culture are valued too. Conversely, females are perceived as associated with nature, and both are devalued. Contrary to other feminist movements that seek to impose women's power over men, eco-feminism emphasizes shared power and women's quest for power from within. As an eco-feminist writer and activist Greta Gaard asserts,

Drawing on the insights of ecology, feminism, and socialism, ecofeminism's basic premise is that the ideology which authorizes oppressions such as those based on race, class, gender, sexuality, physical abilities, and species is the same ideology which sanctions the oppression of nature. (Gaard, 1993, p. 1)

Mary Mellor (1997) defines ecofeminism as "a movement that sees a connection between the exploitation and degradation of the natural world and the subordination and oppression of women" (p. 1). In short, eco-feminism is a combination of feminist studies and environmental issues, and a reaction to the male domination over women and nature. Historically, women have been defined according to their natural constructs, i.e., "mother and virgin," since they are, by nature, closer to the natural world and farther away from the industrial man. Based on this premise, some eco-feminist writers, such as Margaret Atwood in her novel Surfacing (1972), clearly delineate gender roles and pit male against female and nature against man. In contrast, some eco-feminist writers, such as Annie Dillard in her novel 
Pilgrim at Tinker Creek (1974), attempt to create a balance and unity among, instead of between, males and females.

Mies and Shiva (1993) observe from a historical perspective that women were pioneers in preserving environmental integrity:

...everywhere, women were the first to protest against environmental destruction. As activists in the ecology movements, it became clear to us that science and technology were not gender-neutral; and in common with many other women, we began to see that the relationship of exploitative dominance between man and nature (shaped by reductionist modern science since the 16th century) and the exploitative and oppressive relationship between men and women and prevails in most patriarchal societies, even modern industrial ones, were closely connected... (p. 3)

Eco-feminism is often challenged because it does not adhere to the accepted norms that characterize social movements. In particular, it is often questioned because eco-feminism does not entail direct action. As Brammar (1998) explains,

One of the areas where ecofeminism is found lacking is the traditional paradigm of social movements in the area of action. The common view is that social movements engage in protest and direct action; however, ecofeminism calls for consciousnessraising, healing, and communion with nature. There is little direct action. Some call for concern and to be involved in crucial issues. Others call for intellectual work to form a holistic conception of ecofeminism. (para. 6)

Although eco-feminism does not entail direct action, it consists of diverse perspectives and "has roots in the wide variety of feminisms, e.g., liberal feminism, radical and social feminisms, black and Third World feminisms" (Warren, 1997, p. 4). However, according to Brammer (1998),

...there is no group of ecofeminists, no declared leader, and no vague form of organized activity (other than a few intellectual conferences and books). A few organizations have included the word "ecofeminism" in their title, such as Ecofeminists for Animal Rights, but they are not a subgroup of the larger Ecofeminists. In addition, most groups that can be identified as ecofeminists in nature do not identify themselves as ecofeminist. (para. 6)

The perspective that relates most to Michelle Cliff's Abeng, is post-colonial ecofeminism, which entails "the 'double-bind of being female and being colonized" (Andrea, 
2008, p. xi). Adherents of this perspective recognize that the oppression of women and the exploitation of nature are connected to colonialism, neo-colonialism, race, class, and caste. Those women who were victims of colonization were "repeatedly naturalized as objects of heritage to be owned, preserved, or patronized rather than as subjects of their own land and legacies" (Rob, 2005, p. 233). Post-colonial eco-feminists respond to oppressive practices in a historical and sociological view of mutually reinforcing dualisms. The use of both "reason" and "nature" in the discourse of post-colonial eco-feminism provides a basis for considering forms of oppression other than those solely based upon gender. Hence, this type of ecofeminism provides a model of oppression that is integrated among human beings, where some function as the oppressed while others function as the oppressor. According to postcolonial eco-feminists, oppression results from the lack of recognition that everything and everyone is interconnected and functions best when empowered. Indeed, there is a recognition that the human and the natural are historically interwoven, as each depends upon the other as the instrument of their survival and longevity.

Cultural eco-feminists recognize that the patriarchal mindset is only one factor among many that can be held accountable for the various forms of oppression and its consequences, especially in nature. In this context, "cultural [eco] feminism reclaims women-nature connections as liberating and empowering expressions of women's capabilities to care for nature" (Warren, 2011, p. 5495). The connections between women and nature are "embedded in deep social and psychological structures... resurrection of pre-patriarchal religions and spiritual practices ...[thus] making women's ways of knowing and moral reasoning better suited to solving environmental problems" (Warren, 2011, p 5495). McGuire (2011), for example, notes that patriarchy is only 5,000 years old, whereas the human dislocation from nature has been in effect for much longer, since the domestication of plants and animals at least 20,000 years ago. Indeed, through their first attempts at dominating nature, rather than by direct association with the patriarchy, human beings cause the separation between themselves and the natural. Patriarchy, however, can be said to have cemented this process through social oppression. The role of eco-feminism, then, can be described as an examination of ways in which this separation can be remedied on both the social and ecological levels. This has become important in terms of human relationships and has also become vitally important in terms of human survival.

Michelle Cliff, a Jamaican-American novelist, poet, and essayist, is notable for her works about former British colonies in the West Indies. Her focus is on the challenges women, in particular, face when trying to overcome gender and race constructs in their search for an 
authentic, individual identity. From a post-colonial eco-feminist perspective, Cliff depicts the relationship between one's identity and the land in which one resides or calls "home." When writing about her homeland, Cliff "attempts to construct narratives that map the history of black, white, and mulatto Jamaica, mixing genres of narrative-historical, autobiographical, and myth--to achieve a dialectical representation of the West Indian experience" (Edmonson, 1993, p. 182). In Abeng, Cliff gives us a glimpse into her personal search for identity and offers a retelling, revisionist lens from which to view the effects of colonialism - the loss of people's identities and power over their land. Cliff explains that her intent in writing the novel was to "revision."

In the sense of re-visioning something, not in the sense of revising as in correcting it, or editing it, but in trying to see something from a different point of view [...] a colonized history, a history that's been interpreted from a European perspective only. (Clawson, 2002, as cited in Chassot, 2018 p. 11).

Cliff's revisionist approach used in Abeng is continued in the sequel, No Telephone to Heaven. Although the latter will be mentioned as an epilogue to the discussion of Abeng, it will not be discussed extensively.

The novel's title, Abeng, means a conch shell, a common word in the Caribbean, especially Jamaica (Oxford Dictionary). Moreover, Neil (2015) states that the novel's title Abeng is "a reference to the Maroon guerrillas that fought against the British — the "abeng" is the action of using a conch shell as a trumpet, a war-cry. This is Clare's war-cry, and like its predecessor, it's raw and powerful" (para. 4). In the colonial West Indies, this shell was used to call slaves to the cane fields and relay messages between the Maroon armies. In 1655, the British took Jamaica from Spain, and at this time, the Maroons, who were slaves, escaped from their Spanish-owned plantations. Cliff uses this novel, which takes place during the transition period of independence in Jamaica, as a call to challenge and combat imperialists' and colonists' modes of environmental and social dominance.

When writing post-colonial eco-feminist literature, Cliff and other authors use a geographical locale or "place," which serves as the impetus for the protagonist's selfdevelopment and attainment of identity. Place represents an environment, which entails cultural artifacts - the economic, political, social, and religious aspects of people's surroundings. A sense of place is crucial because, "[i]t is here that the special post-colonial crisis of identity comes into being; the concern with the development or recovery of an effective identifying relationship between self and place" (Ashcroft, Griffiths \& Tiffin, 1989, p. 8). Jamaicans are now displaced and their lineage is disjointed. They are descendants from one or more of the 
following groups: European colonizers, African slaves, or Chinese and Indians, who were indentured laborers after slavery was abolished. The Tainos, who were the indigenous people, were exterminated, the victims of war, slavery, and disease, which resulted after Christopher Columbus claimed the West Indies for Spain in 1494.

Cliff uses a coffin as an insight into Jamaica's dark history, a history that not even its own people quite understand. Through the re-creation of Jamaica's colonial history, Cliff exposes the harsh reality of its past that had been buried underground like a coffin, which "contained the remains of a hundred plague victims, part of a shipload of slaves from the gold coast, who had contracted the plague from the rats on the vessel which brought them to Jamaica" (p. 7). In the novel, the dark history of Jamaica's past is contrasted with the promise of a new beginning, particularly in the references to places and occurrences in nature. Cliff has her characters interact with nature to call for the possibility of a harmonious bond between humans and their environment, which is the ideal world that eco-feminists desire. The novel's opening scene includes a depiction of the height of the mango-growing season. Cliff describes the mangoes as growing:

All over and each variety was unto itself--with its own occasion and use.

In the yards around town and on the hills in the country, spots of yellow, pink, red, orange, black, and green appeared between the almost blue elongated leaves of the fat and laden trees--and created a confusion underneath. (Abeng, p. 4)

Not only this does provide a description of the burgeoning fruit, but also it symbolically represents the Jamaican people. They were products of biracial relationships during colonization, and thus, now have a variety of skin colors, which often causes confusion when determining their identity.

Abeng is a bildungsroman in which Cliff lights the pathway to finding identity and "place" through the main protagonist, Clare Savage, a "twelve-year-old Christian mulatto girl ... walking through her life according to what she had been told, not knowing very much about herself or the past" (p. 71). The lack of a true identity because of displacement is one of the common themes in post-colonial eco-feminist literature. The root of Clare's skewed identity is her family dynamic and relationships with her father, Boy Savage, and her mother, Kitty Savage. In essence, "[s]he felt split into several parts--white and not white, town and country, scholarship and privilege, and Boy and Kitty" (p. 119). In Jamaican society, color, race, gender, class, and language classify people. Race is an issue for Clare because she does not know if she is considered black or white. Clare notices her sister is treated differently because she has darker skin than Clare and her father, Boy, even though she shares Clare's DNA. In Jamaican society, expectations for one's role in society were based on skin color. Because Clare is light- 
skinned, she is expected to obtain a high educational level. However, Clare's sister, who is dark-skinned, is expected to be a caretaker like her mother. This expectation is reinforced by Clare's parents. The gifts she and her sister received represent the roles they were expected to play in the future: "Last Christmas her sister had gotten a pretty stove and a Tiny Tears Doll; Clare was given a reading lamp and a desk" (p. 68). The more that Clare experiences deferential treatment based on her skin color, the further she is led into her journey to find her identity.

Clare recognizes that her father is considered superior to her mother because he is both male and light-skinned, whereas her mother is female and dark-skinned. Clare is therefore associated with the parent whom she resembles. She becomes her father's daughter because he, like her, is light-skinned. Clare's sister is considered her mother's daughter because she, like her, is dark-skinned. Although Clare knows that she shares both parents' genes, she actually knows more about her father's history and hardly anything about her mother's history. Clare's need to experience a sense of inner completeness originates from her lack of maternal interconnectedness and environmental detachment. For example, Clare's mother is emotionally distant throughout the novel. Clare discovers the impossibility of intimate disclosure with her mother: "Clare did not tell her mother anything which was close to her. She avoided any subject which she thought would make her mother uncomfortable" (p. 80). Clare's lack of emotional bonding with her mother caused her to suppress her feelings and avoid expressing her concerns and anxieties. This state of isolation forces Clare to attach a natural place to her psyche for solace.

Clare has a desperate need for friendship, a bond with someone who is like herself. She does not have the mother/daughter bond and relationship that satisfies the need to be loved and nurtured. Clare obtains insight into her true self when she meets Zoe, who becomes her best girlfriend. Examining their friendship through the post-colonial eco-feminism lens reveals that because they are of different colors and classes, they are not judged the same by society. Although they share the same geographical location, Jamaica, their places in it are in opposition to each other. They are contrasts in many areas: Clare is light-skinned and privileged. She lives in an upper class neighborhood in the city of Kingston and goes to an exclusive school. Zoe is dark-skinned and poor. She lives in a one-room cabin with her mother and attends a oneclassroom school. Another distinction is that Zoe knows her place in society and Clare is still struggling with her identity. Although they are the same age, Zoe is more mature and understands quite well Jamaica's social hierarchy and her place in it.

When Clare is given a chance to prove to Zoe that she accepts her as her equal, she fails. When Clare's grandmother buys her a new swimming suit, Zoe wants to try it on, but Clare will not let her: "Oh, man; dis is fe me suit..." (p. 101). Zoe had never had a swimming 
suit like Clare's; she wanted to try it on to see what it was like. Zoe understands just how she is distant from her "friend," Clare, and how separated she is from people of a higher class, race, and education. Clare reinforces this expectation by giving Zoe more reasons to believe that she is inferior to her best friend. Zoe realizes that her future is already planned out, no matter how smart woman she is. She is considered not to be the "right" color, class, race, or gender. She clearly understands that the woman she will become is one that is marked for failure.

Nevertheless, Zoe is in harmony with her identity and place in the country despite Clare's identity and place, which is the town. Zoe introduces Clare to the wonders of nature in the country. When they play together, they interact with their environment, achieving oneness with the nature aspect of eco-feminism theory. Zoe and Clare are connected, "[n]ot by school or town," but "by bush and river and mountain" (p. 95). Instead of toys, they use "mud from the roadbed to make dishes and cups for their tea parties" (p. 93) and "climb a star apple or custard tree" (p. 94). During one of their outdoor activities, when they are sunbathing by the river, Zoe calls Clare a "buckra," which means she acts like a British white woman. Clare denies this and retorts, "Me no town gal. And me no buckra" (p. 118). In that climactic scene, Zoe responds:

Wunna is town gal, and wunna papa is buckra. Wunna talk buckra. Wunna leave here when wunna people come fe wunna. Smaddy? Wunna no is smaddy already? Gal smaddy. Kingston smaddy. White smaddy. Dis place no matter wunna a-tall, a-tall. Dis here is fe me territory. Kingston a fe wunna. Me will be here so all me life-me will be a marketwoman like fe me mama. Me will have fe beg land fe me and fe me pickney to live pon. Wunna will go a England, den maybe America, to university, and when we meet later we will be different smaddy. However, we is different smaddy now. (Cliff 118)

Here is a sense of postcolonial diasporas as represented by cross-cultural environmental mixed identities in quest for establishing a transatlantic belonging. Language and the land have become clear determiners for social status. Elvira Pulitano rightly observes that "Creole, the language of the plantation system, associated with sugar cane and sugar cane production, debased as inferior and uncultivated, labeled as a bastardized form of speech" (p. 188) Pulitaon states that this language "bears all the marks of the Jamaican landscape within which Clare slowly comes of age" (p. 188).

Zoe knew by Clare's response that she did know her place and denied her privileged status. 
Zoe knew that Clare could not really understand what she had said. She did not think that Clare had any idea of what being poor really meant. What being dark really meant. Why these things would always come between them. She cared for her playmate but she saw that she was limited. (p. 119)

Although Clare denies that she is privileged, her actions prove otherwise. A couple of hours after the conversation in which Zoe called Clare a "buckra," one of the local laborers walks toward the girls and surprises them. When Clare tells the laborer to go away, she switches from speaking in broken English, as she does when she is talking Zoe, to Standard English: "Get away, you hear. This is my grandmother's land." (p. 122). She assumes a superior stance and treats the laborer as an inferior, "relying on the privilege she said she did not have" (p. 122). Another bearing of Clare's saying, "This is my grandmother's land," is a clear though indirect assertion of a superior identity as a Miss Mattie's granddaughter versus Zoe, a daughter of a colored market woman.

Language has become the main criterion for classification. If one speaks well in Jamaica, one is thought to be well educated. This is another area in which Zoe differentiates between her identity and Clare's identity. Zoe sees that Clare's language gives her privilege that she (Zoe) does not have because of her dark skin and low social status. According to Alleyne (1985), "The language situations existing in the Caribbean are mirrors through which the complex cultural history of the region may be observed" (p. 158).

The one thing they have in common is that they both are females and are victims of oppression in a patriarchal society. A key event in the novel illustrates how Clare tries to overcome gender inequality imposed by society. Paradoxically enough, Clare, who fails to practice equality with her female fellow and comrade, Zoe, tries to achieve equality with males. In quest for her identity, Clare wants to show that she is equal to males by shooting an animal. The activity of hunting and killing of animals is traditionally done only by men, and Clare wants to show her society that she is capable of doing the same as the males. So Clare, armed with her grandmother's shotgun, and Zoe hunt for a wild boar named Master Cuffy. Clare misses the boar and instead shoots and kills her grandmother's prize bull. This misfiring causes her to miss the opportunity to claim her place as equal to that of males. She is looked at as just a female who cannot shoot like a man. Clare does not yet know about women's possibilities to become empowered and have self-confidence about their abilities.

On the pathway to identity and self-discovery, with the help of family, Zoe, and society, Clare is able to better understand who she is. Abeng's concluding episode consists of a dream Clare has that marks the next phase of her journey: "Clare dreamed that she and Zoe were fistfighting by the river in St. Elizabeth... when she woke, the power of the dream was still with 
her" (p. 165). At this junction, her relationship with Zoe is at a dead end, because they are unable to reconcile their differences, which impede their ability to be true friends who accept each other unconditionally. Clare accepts that she is not like Zoe, and is, in fact, of mixed lineage and privileged background. She has accepted this as she continues to solidify her identity.

In the sequel to Abeng, No Telephone to Heaven, Clare is still on the path to selfdiscovery. She is now an adult and attends college in London. During a college break, she meets a member of a resistance movement in Jamaica who persuades her to join it. She agrees because she acknowledges that her roots are in Jamaica, not England. When she returns, she studies Jamaican oral history and culture and then teaches language arts and history to schoolchildren. The resistance movement of which she is a member attack a film crew to stop them from making a documentary about Jamaica's struggle for independence. The police are informed of their plans by a traitor and stop the attack with gunfire. All of the members of the movement, including Clare, are killed. Clare's last moments consist of memories of the Jamaican language, which fully resolves her identity crisis. She "remembered language," in terms of European colonizers, English, French, in terms of slavery, "whip-whip-whip...the back-raw, back-raw, back-raw." She lets the language of oppressors go and uses the sounds of birds, which are the sounds of nature: "cutacoo, cutacoo, cutacoo...cwa cwa cwa cwaah cwaah cwaah" (p. 208). This is Clare's attempt to reconcile the dualism of her life, her education in London and the return to her Jamaican roots. The bird sounds suggest she has found freedom.

\section{CONCLUSION}

The themes and characters in Michelle Cliff's quasi-autobiographical novel, Abeng, move from an area of clear dichotomy to a gray area between disunity and togetherness, a fusion of classic male emotions and actions (fearless, stoic, oppressive) with classic female attributes (loving, compassionate, gentle). These authors' purpose is to call for balance and unity, not stereotypes. Their works support the fusion rather than the fission of genders, place, and emotions. Both the works have important messages for men and women. As a result of the contributions of eco-feminist writers, "[f]rom the seeds of a common need for social reform between feminist and ecological activism, ecofeminism has grown to purport an inextricable relationship between social equality and environmentalism" (Messer, 18).

In Cliff's novel, the main point is that knowing one's past and place in history, one's roots, is vital for self-development. If one is denied this knowledge, he or she is denied an identity. Although eco-feminism is not a typical social movement because it does not have direct action, the value of presenting and analyzing literary works, such as these, through an eco-feminist lens is that it spreads awareness of the plight of the environment and the necessity 
for both men and women to join together to protect the environment and ensure an ecological balance:

If we are women, we have as a group an interest in escaping our ancient domination. We women also have an interest, which we share with all other living creatures, and among them with men, in a sound and healthy planet, in sound, healthy and balanced ecosystems and in a sustainable and satisfying way of living on the earth. (Plumwood, 1993, p. 7)

Therefore, it is important to continue highlighting those female authors whose works embody two main categories of literary works. Those who address ecofeminism from an external viewpoint, in which new directions, philosophies, and concepts are identified for their connection to current trends in society; and those who address ecofeminism from an internal viewpoint, in which the works promote a healing paradigm, based on environmental ethics, which cures the ill-treatment of nature and women.

\section{REFERENCES}

Alleyne, M. (1985). A linguistic perspective on the Caribbean. Washington, D.C.: Woodrow Wilson International Center, Latin American Program.

Andrea, C. (Ed.). (2008). New directions in ecofeminist literary criticism. Cambridge: Cambridge Scholars Publishing.

Ashcroft, B., Griffiths, G. \& Tiffin, H. (1989). The empire writes back. New York: Routledge. Brammer, L. R. (1998). Ecofeminism, the environment, and social movements. National Communication Association Conference. Retrieved from http://homepages.gac.edu/ lbrammer/Ecofeminism.html.

Chassot, Joanne. (2018). Ghosts of the African diaspora: Re-visioning history, memory, and identity. Hanover, New Hampshire: Dartmouth College Press.

Clawson, J. (2002). Re-visioning our history: An interview with Michelle Cliff. Nidus, Available at: www.pitt.edu/ nidus/archives/spring2002/cliff1.html

Cliff, M. (1984). Abeng. Penguin Group: New York.

Cliff, M. (1989). No telephone to heaven. New York: Vintage International.

Edmondson, B. (1993). Race, privilege, and the politics of (re) writing history: An analysis of the novels of Michelle Cliff. Callaloo, 16, 180-91.

Emerging. http://eve.enviroweb.org.

Gaard, G. (Ed.). (1993). Ecofeminism: Women, animals, nature. Philadelphia: Temple University Press.

Glotfelty, C. \& Fromm, H. (Eds.). (1996). The ecocriticism reader. Athens and London: The University of Georgia Press. 
McDowell, E. (1992). Power and environmentalism in recent writings by Barbara Kingsolver, Ursula K. Le Guin, Alice Walker, and Terry Tempest Williams. Eugene, OR: University of Oregon.

McGuire, C. (2011). What is ecofeminism anyway? Eve Online: Ecofeminist Visions

Mellor, M. (1997). Feminism \& ecology. New York: New York University Press.

Messer, M. (2007). Writing the world: Ursula K. Le Guin and Margaret Atwood's literary contributions to ecofeminism. Western Kentucky University: Honors College Capstone Experience/Thesis Projects.

Mies, M. \& Shiva, V. (1993). Ecofeminism. London: Zed Books Ltd.

Mies, M. \& Shiva, V. (2010). Ecofeminism. New Delhi: Rawat Publications.

Neil, C. M. (2015). Abeng by Michelle Cliff. The California journal of women writers. https://journalwomenwriters.wordpress.com/2015/02/10/abeng-by-michelle-cliff/

Oxford English and Spanish Dictionary. Available at: https://www.lexico.com/definition/abeng

Plumwood, V. (1993). Feminism and the mastery of nature. London \& New York: Routledge.

Pulitano, E. (2016). Transnational narratives from the Caribbean: Diasporic literature and the human experience. Routledge Interdisciplinary Perspectives on Literature. London \& New York: Routledge.

Rob. N. (2005). Environmentalism and post colonialism. In A. Loomba, S. Kaul, M. Bunzl, A. Burton, \& J. Esty (Eds.). Postcolonial studies and beyond (pp. 233-251). Durham, London: Duke University Press.

Warren, K. (1997). Ecofeminism: Women, culture, nature. Bloomington: Indiana University Press.

Warren, K. (2011) Feminist theory: Ecofeminist and cultural feminist. International Encyclopedia of the Social and Behavioral Sciences, (Neil J. Smelser, Paul B. Baltes, Eds). Pergamon, pages 5495-5499. https://doi.org/10.1016/B0-08-043076-7/03949-8

Warren, K. J. (2001). Feminist Theory: Ecofeminist and Cultural Feminist. Elsevier, Inc. 